\title{
Policy Implementation of Tour Guides License in Maintaining the Quality of Tourism in Bali Province
}

\author{
Kadek Rianita Indah Pratiwi ${ }^{* 1}$, Choirul Saleh², I Gede Eko Putra Sri Sentanu ${ }^{2}$ \\ ${ }^{1}$ Master of Public Administration, Faculty of Administrative Sciences, University of Brawijaya Malang, Indonesia \\ ${ }^{2}$ Faculty of Administrative Sciences, University of Brawijaya Malang, Indonesia
}

\begin{abstract}
Bali Regional Government intervenes tour guides profession by implementing the licensing policy. This phenomenon is associated with the increasing number of tourist visits to Bali and the important role of tour guides in maintaining tourism quality. This research aimed to analyze the implementation of the licensing policy for tour guides in Bali. Practically, this research can provide an understanding of policy implementers to pay attention to aspects of implementation in tour guide licensing policies in Bali. Then academically, this research can be a reference for tourism policy research related to implementation theory. A qualitative approach with the case-study analysis applied to this study. The research conducted semi-structured interviews, observations, and documentation studies in gaining insights from research data. In this research, we found that licensing policy for tour guides in the process of implementation found deficiencies in aspects of policy objectives and standards, policy resources, communication, socio-economic and political environments, and characteristics and disposition implementers.
\end{abstract}

Keywords: License, Policy Implementation, Tour Guides.

\section{INTRODUCTION}

Bali Tourism is still a prime area for both domestic and foreign tourists. It is evident from the data of Province Bali Central Bureau of Statistics (BPS Provinsi Bali) that the number of tourist visits to Bali has increased every year (Fig. 1). Bali tourism development certainly involves various parties, both the macro party, i.e. the government, and the micro party, i.e. tour guides.

The main responsibility of tour guides is to accompany tourists. More importantly, they have a role to create tourism quality $[1,2,3]$. It is due to the tour guides' function as the bridge of communication between local host communities and visitors [2]. Much of the quality of the tourist experience depends on how tour guides do their job [3]. In Indonesia, tour guides are often referred to as the nation's ambassadors or frontline because they connect tourist attractions and visitors. Tour guide's quality and professionalism are the prerequisites for this commitment because tour guides need to maintain a good and positive image about the area they present to tourists. Research shows tour guides service quality that guides provide influences the positive image of tourist attraction

\footnotetext{
${ }^{*}$ Correspondence address:

Kadek Rianita Indah Pratiwi

Email : rianitaindah232@gmail.com

Address : Faculty of Administrative Sciences, University of Brawijaya, Mayjen Haryono No. 163, Malang, 65145.
}

(DTW) and tourist satisfaction [4,5]. The research projects, if the tour guide carries out his role with good quality and ethics, then the quality of tourism activities in Bali is also maintained. Also, the increase in the number of visits to Bali must be supported with qualified tour guides [6].

The Regional Government of Bali strives to improve the quality of the tour guide profession as an indicator of maintaining the quality of tourism in Bali. This is done by implementing a policy instrument that can be used to control in the form of Bali Regional Regulation Number 5 of 2016 concerning Tour Guides. Regional regulations require that everyone carrying out tour guide activities must have a license. Tour guide licenses are government regulations so that tour guides have legitimate administrative recognition. In addition, the licensing policy for tour guides is an acknowledgment of their professionalism because basically, the license is the fulfillment of standardization and professional certification.

The license policy for tour guides in Bali is implemented as an effort by the regional government to achieve the goal of controlling and improving tour-guide quality. Implementation is always in connection, specifically with policies or as a specific response to problems that exist in society [7].

Nowadays, several studies have put their attention on implementation studies because implementation focuses more on problems commonly faced when the government tries to 
achieve its policy intentions through implementation $[8,9]$. The problems in the tourism policy implementation are due to the lack of the institutional management, relationship, and coordination structure between organizations, and socio-economic environments [8].

In addition, implementation problems are associated with the relationship and bargaining power between interest groups [9], and the tendency of implementing attitudes that influence the implementation process $[10,11]$. These aspects form the relationship between policy and the performance of policy implementation [11]. With that, the fate of the policy implementation will lead to success or failure in the implementing depends on the complexicity of the organization and the parties involved.

Based on the above consideration, this research aimed to analyse the implementation of the license policy for tour guides in Bali Province in the form of Regional Regulation No. 5 of 2016, which focuses on the aspects of the policy implementer and tour guides' attitudes on the government policy that regulates their work. This research contributes to the understanding of license policy implementation for tour guides by considering aspects that link the complexity of implementing organizations and the implementor's attitude.

\section{MATERIAL AND METHOD}

This research is qualitative research with a case-study approach. In specific, the research location restricted to the research area, Bali Province. Bali is one of the provinces in Indonesia that has regional regulations for tour guides and is currently still potentially high in bringing tourists (Fig. 1).

The research sites include Bali Government Tourism Office, the Office of the Regional Leadership Council of Tour Indonesian Tour Guides Association of Bali (DPD HPI Bali) and several tourist attractions on Bali Island including Tirta Empul Gianyar Temple, Kerta Gosa Klungkung Park, Penglipuran Village Bangli, Bajra Sandhi Museum in Denpasar, Pura Tanah Lot Tabanan, and Pura Besakih Karangasem.

The research began with determining data collection techniques. The primary data were obtained through interviews, while the secondary data obtained through non-participant observation and documentation studies. Semi- structured interviews conducted with informants, namely interview, which in line with the research focus, but not to limit the informants' opinions to provide more clear and free information. Informants were selected using a purposive sampling technique based on the consideration that they were directly related to the implementation of a tour-guide license in Bali.

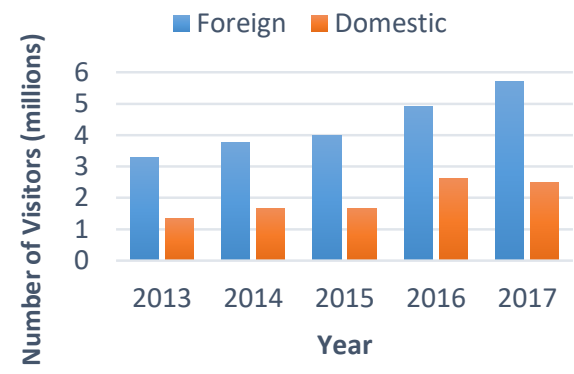

Figure 1. Number of Foreign and Domestic Guests in Bali, 2013-2017

Source: Bali Province in Figures [1]

The informants are the ranks of tour-guide and executor policymakers in tourism activities in Bali. The informants selected fourteen people, including the Head of Institutional Section of the Bali Government Tourism Office (Disparda Bali), Chair of the Association of Bali Regional Indonesian Guides Association (DPD HPI Bali), Head of Research and Development section tour associations and Bali travel agencies (ASITA Bali), Investigators Civil Servants of Bali Public Order Enforcers (PPNS Satpol PP Bali), and ten tourguides to explore more in detail the implementation of licensing policies towards the target group. Ten guides selected purposefully are limited to, tour guides who have managed licenses and are still actively working. The selection of tour guides with the stated criteria was done by ensuring that the targeted tour guide is a member of the DPD HPI Bali and uses the Tour Guides' Identity Card (KTPP).

The secondary data were from observation in the field and documents related to the tourguide licensing policy. The interview data were juxtaposed with the events during the observation and the analysis results of several documents that the researcher found in the field. These two techniques are useful in providing deep understanding and feedback to develop interview guidelines for informants. 


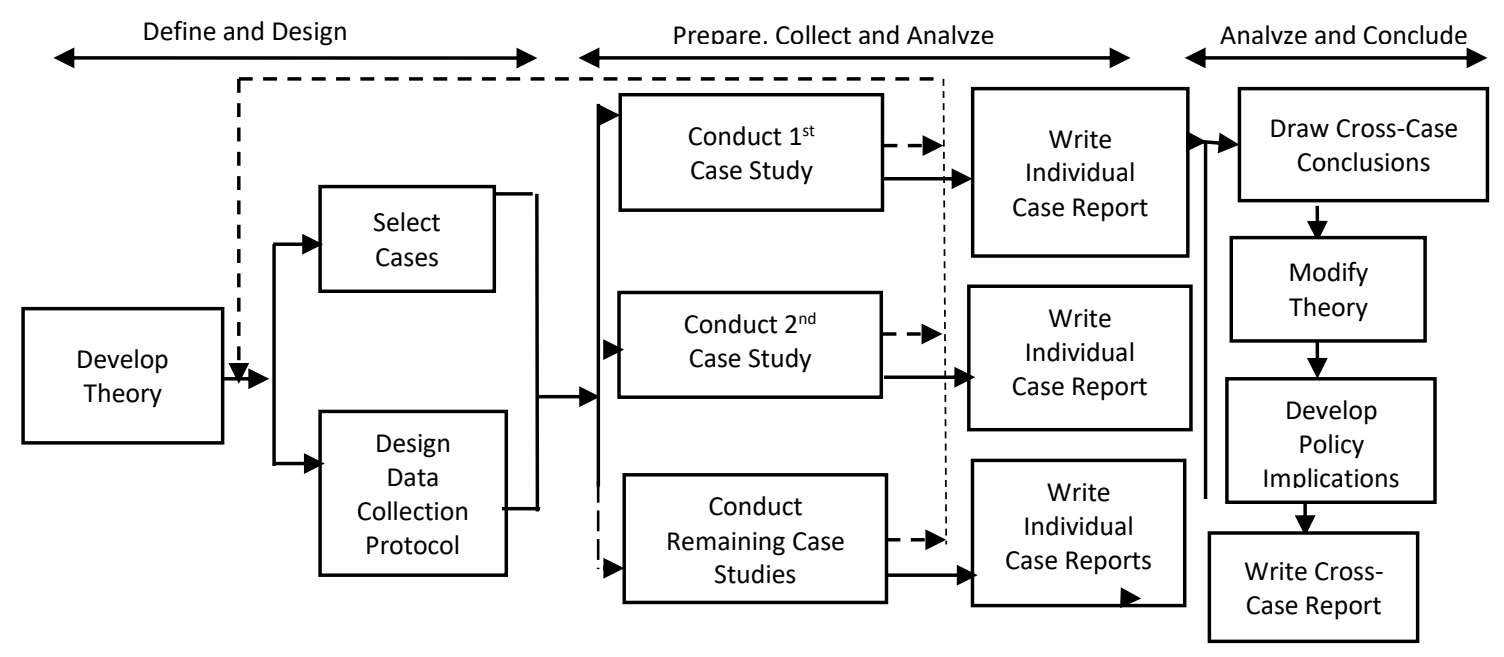

Figure 2. Case Study Data Analysis [12]

\section{Data Analysis}

The data analysis follows the case-study analysis technique by Robert K. Yin, which consists of three steps, namely (1) define and design; (2) prepare, collage and analyse; and (3) analyse and conclude [12]. The analysis used because it allows the researcher to explore social cases and analyse conditions in the field as a whole and specifically. The stages of the casestudy analysis process can be seen in Figure 2 .

\section{RESULT AND DISCUSSION}

\section{Characteristics of Informants}

The characteristics of the informants in this study were selected by informants involved in implementation of tour-guide license policy, both policy makers and policy objectives. A brief explanation of the characteristics of informants can be seen in (Table 1). Characteristics consist of gender, age, and education.

\begin{tabular}{|c|c|c|}
\hline No. & Category & Total \\
\hline \multirow[t]{3}{*}{1.} & Gender & \\
\hline & Male & 11 \\
\hline & Female & 3 \\
\hline \multirow[t]{5}{*}{2.} & Age & \\
\hline & $21-30$ years & 4 \\
\hline & $31-40$ years & 1 \\
\hline & $41-50$ years & 6 \\
\hline & $>50$ years & 3 \\
\hline \multirow[t]{5}{*}{3.} & Education & \\
\hline & Senior High School & 6 \\
\hline & Bachelor (S1) & 7 \\
\hline & Masters (S2) & 1 \\
\hline & Doctorate (S3) & 0 \\
\hline
\end{tabular}

\section{License Policy for Tour Guides in Bali}

The researcher adopted the implementation theory as recommended by Van Meter and Van Horn to provide a comprehensive understanding of policy implementation in the context of the implementer and his attitude. Thus, this section divided into three parts. The first part discusses the License Policy for tour guides consisting of policy objectives and standards, and the resources needed in implementing. The second part discusses the implementors of the license policy. This section consists of sub-sections of inter-organizational communication, organizational characteristics, and economic, social, and political environments. The third part discusses the tendency of tour guides' attitudes towards the licensing policy for their work.

\section{License Policy Objectives and Standards}

Bali Tourism is currently developing. Local governments are always trying to make improvements to all components to maintain its quality. One of them is by ratifying Bali Regional Regulation Number 5 of 2016 concerning Tour Guides. This regulation requires tour guides to be licensed. The implementation of accreditation, professional certification, and licensing is a number of quality assurance measures [13]. It is in accordance with the Law of the Republic of Indonesia Number 10 of 2009 concerning Tourism, which mandates every local government to have standardization and certification for tourism workers and from the Government Regulation of the Republic of Indonesia Number 52 of 2012 concerning Competency Certification and Business Certification in Tourism. Based on these laws, the 
provision of license ownership for tour guides in Bali Province was carried out by standardization and certification.

Tour guides who fulfill the license requirements will get a Tour-Guide Identification Card (KTPP) (Fig. 3). These requirements include Indonesian citizen, having a valid National Identity Card (KTP), residing/domicile in a Regency/City in the Province of Bali for a minimum of 2 (two) years, age of 19 years or married, having Knowledge Test Certificate on Balinese Culture held by the Bali Government Tourism Office, having a Tour-Guide Competency Certificate held by Professional Certification Institutions, lowest educational level of Senior High School (SMA or SMK) and/or having a minimum 2-year internship experience as a tour guide at the Travel Agent in Bali, being drug free, physically and mentally healthy, and free from police records.

Regional Regulation Number 5 Year 2016 generally aims to control and improve the quality of tour guides in Bali. Bali Tourism Development, which based on Bali Culture, is the main attraction for tourist visits to Bali Province. The government encourages the license policy to regulate a number of tour guides who are not responsible for maintaining Balinese culture. It caused by the fact that unlicensed tour guides tend to walk tourists to shop and cannot explain Balinese Culture. Given that the tourism situation in Bali is still considered a concern, as one of the nation's ambassadors, the tour guide must be extra careful and critical in explaining information to each tourist guided [6].

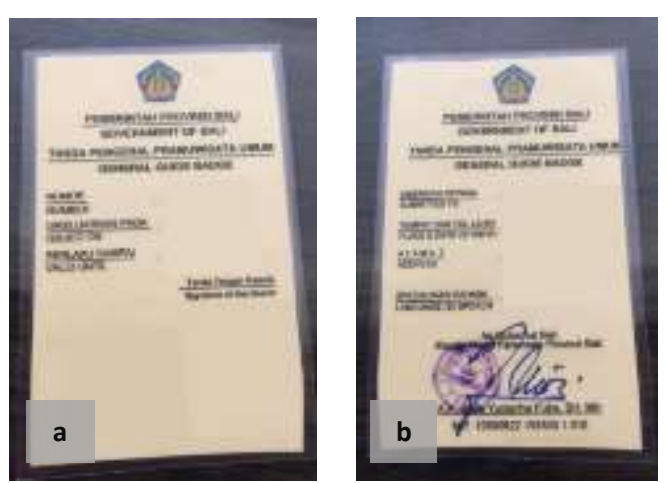

Figure 3. Tour Guides Identification Card (KTPP), a) Front, b) Back. (Source: Personal Documentation)

Based on interviews about the objectives, the tour guides agree with the government because what they understood and preserved in Bali is the expectation that tour guides could also maintain a positive image of Bali tourism while guiding tourists. However, tour guides have a different view from the government on the standards. In general, tour guides argue that 1 ) the requirements required by the regional regulation cannot measure their ability compared to their experience, and 2) the standards provided are not in accordance with the challenges for work complexity as said by the Chair of DPP HPI Bali:

"The association has different perspective from the government. It is okay if the prospective tour guide joins competency certification. However, for the tour guide who has an experience of 15 to 20 years, a professional in the field of guidance, the certification test does not provide additional knowledge. It is actually a contradiction with the basic meaning of competency certification."

The different views of tour guides and the government are essentially objection to the competency certification requirements that must be extended every three years, which causes tour guides to be reluctant to comply with the applicable rules. It is important to understand the intent of a standard and policy objectives. The implementation may fail because they reject or do not understand the objective of policy [11]. The government requires competency certification to maintain and improve the performance of tour guides who are always dynamic in global developments. However, they think that their work is not solely enforced by tour-guide certification by Professional Certification Institutions (LSP), but appears in their work routines. This view arose because the certification material and system tested did not provide additional knowledge compared to their experience in the field. Concerns in this certification program development still occur in developing countries [14]. Objections to guides for license policy standards lead to impeding implementation.

\section{Resource Required}

The resources needed for a policy certainly vary from access to information, finance, to human resources, and others. Resources needed in the implementation of tour-guide policies are in the form of human resources and financial resources.

The number of human resources needed in the service and issuance of KTPP and the control of legal tour guides shown in Table 2. The KTPP service is one-door service in DPP HPI Bali, but 
the number of available HR is only four persons. The quantity in the organization is not sufficient because the employees at DPD HPI Bali are also busy to work as a tour guide. It inhibits KTPP issuance service, causing complaints from KTPP applicants. For example, the applicant had submitted the files in September 2018, but until January 2019, the process had not finished. It caused the applicant to complain because the KTPP issuance service was too long.

Table 2. Agencies, Activities and Number of Human Resources (SDM)

\begin{tabular}{llc}
\hline \multicolumn{1}{c}{ Agencies } & \multicolumn{1}{c}{ Activities } & $\begin{array}{c}\text { Number of } \\
\text { human } \\
\text { resources }\end{array}$ \\
\hline DPD HPI Bali & KTPP Services & 4 \\
$\begin{array}{l}\text { Bali Government } \\
\text { Tourism Office } \\
\text { Bali Public Order } \\
\text { Enforcers }\end{array}$ & $\begin{array}{l}\text { Enforcement of } \\
\text { Violations in KTPP }\end{array}$ & 5 \\
\hline
\end{tabular}

This condition also occurs in the implementation of illegal tour-guide control activities. The institution in charge of carrying out tour-guide control is Bali Public Order Enforcers (Satpol PP Bali). In terms of quantity, there was a shortage of members of Satpol PP (Civil servise Police Unit), which were only 11 compared to the complexity of their work because Satpol PP is responsible for enforcing not only the Regional Regulation for Tour Guides but also other 21 regional regulations.

On the other hand, financial resources also needed in implementing the tour-guide policy. In Bali Tourism Service, the budget allocation for tour-guide training activities is small (only 19\%) compared to other activities. The fund is only sufficient to conduct Balinese cultural knowledge testing for 120 people and 1 document (Table 3). The budget provided is still not effective, as seen from the large amount of the budget used for Jegeg Bagus Bali election activities by $62 \%$. Therefore, the budget cannot be maximized for training activities for tour guides. This financial resource limitation makes the tourism service unable to carry out its activities other than Balinese cultural knowledge testing and to provide strong KTPP card printing facilities. The KTPP card only printed to plain paper along with the signature of the Head of the Bali Government Tourism Office (Fig.3.b). This weakness made it possible to duplicate illegal KTPP. This budget limitation has hampered the implementation of activities.

Meanwhile, the costs for fulfilling other requirements in accordance with the prevailing law directly charged to each tour guide. Some tour guides responded that the costs incurred should be balanced with welfare for their work:

"As tour guides have been willing to do licensing, spend expenses and carry out certification, I hope that tour guides in Bali are well organized. Therefore, policies can also help tour guides increase their income, have a positive effect on the sustainability of tour guides."

Based on the explanation above, the budget limitation for tour guides has an impact on the less optimal performance of Bali Government Tourism Office. Besides, it influences the tendency of tour guides' attitudes. When the government lacks the budget and charges each tour guide, it needs to be balanced with incentives or benefits for the people served [10].

Table 3. Tourism Institutional and Human Resource Development Program Budget for 2019

\begin{tabular}{|c|c|c|c|c|}
\hline Program & Performance Indicator & Target & Budget (IDR) & Percentage \\
\hline $\begin{array}{l}\text { Increasing the role of } \\
\text { the community in the } \\
\text { development of } \\
\text { tourism }\end{array}$ & $\begin{array}{l}\text { The number of tourism coaching } \\
\text { participants to tourism awareness } \\
\text { groups and high school. }\end{array}$ & 630 persons & $229,314,416$ & $19 \%$ \\
\hline $\begin{array}{l}\text { Increasing the role of } \\
\text { tourism institutions }\end{array}$ & $\begin{array}{l}\text { The number of tour guides given } \\
\text { training and service standards } \\
\text { academic study }\end{array}$ & $\begin{array}{l}120 \text { persons } \\
\text { and } 1 \\
\text { document }\end{array}$ & 229.314 .416 & $19 \%$ \\
\hline $\begin{array}{l}\text { Increased tourism } \\
\text { human resources }\end{array}$ & $\begin{array}{l}\text { The number of participants in the } \\
\text { election of Jegeg Bagus Bali. }\end{array}$ & $\begin{array}{l}18 \text { tourist } \\
\text { ambassador }\end{array}$ & $729,314,416$ & $62 \%$ \\
\hline
\end{tabular}

Source: Bali Government Tourism Office, 2019 


\section{Policy Implementors}

This section divided into three sub-sections, namely inter-organizational communication, organizational characteristics, and social, politic, and economic environments.

\section{Inter-Organizational Communication}

Communication between organizations must meet the dimensions of consistency and clarity [10]. Stakeholders involved in tour-guide policy implementation in Bali are Bali Government Tourism Office, DPD HPI Bali, and Bali Public Order Enforcers. Hence, good communication among the three must be established. The established communication is coordinative (Fig. 4).

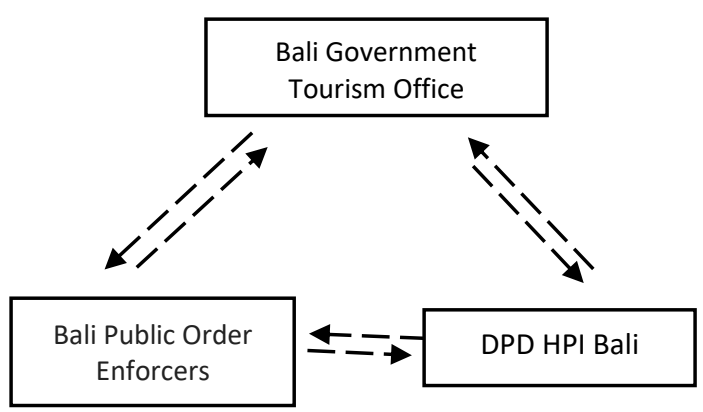

Figure 4. Implementor Relationship Pattern in Tour Guide Lisence (Source: Results of Analysis, 2018) Note. $\quad 4-=$ coordinative relationship

In the consistency dimension, Bali Government Tourism Office always intensively coordinates with DPD HPI Bali and Bali Public Order Enforcers. Communication is intertwined at the events of the Bali Cultural Knowledge Testing carried out every year as well as event invitations or hearings in incidental meeting forums (Fig. 5). The hearing is used to discuss and coordinate important matters related to the implementation of tour-guide policies. In addition, coordination is done by utilizing social media such as WhatsApp or instant messaging.

"During the policy-making till the implementation of policies, there is always coordination among Bali Provincial Government, DPD HPI Bali, ASITA, Bali Public Order Enforcers, and Bali Government Tourism Office. The communication has been well established. If there are problems related to tour guides, these parties will conduct a problem-solving hearing."

The implementation order must not only be acceptable but must how the activities are carried out must also be clearly stated $[10,14]$.
Although the organizations involved have carried out communication, the clarity dimension is also an important factor to consider. It means that the contents of a policy that are more clear and detailed will reduce miscommunication between organizations. The research results support the viewpoint of the two opinions above. The communication factor in the implementation of the tour-guide policy in Bali still faces many obstacles, especially in the clarity factor. The informant Chair of DPD HPI Bali interviewed identified miscommunication between the organizations due to the lack of clarity in the information provided, such as the costs needed.

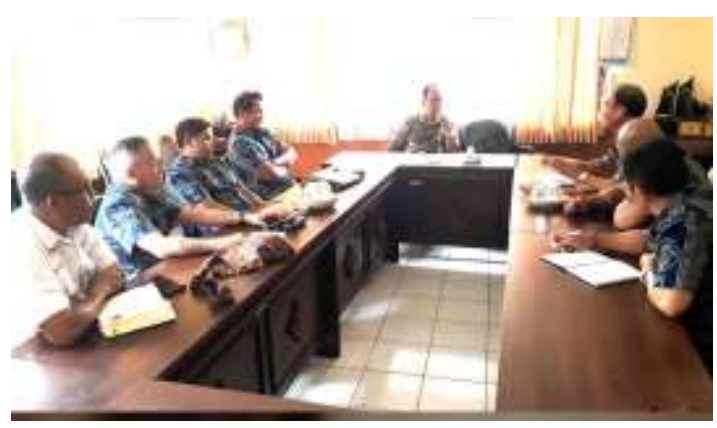

Figure 5. Audience between Implementors. (Source: DPD HPI Bali Documentation)

"We experienced some obstacles because we had misunderstood, like the obstacle of competency certification. At first, we thought that the government would subsidize the license extension. In fact, there were no subsidies for us."

\section{Organizational Characteristics}

Organizational characteristics can be seen from its bureaucratic structure. The bureaucratic structure is defined as characteristics, norms, and patterns of relationships that occur repeatedly in executive bodies that have both potential and real relationships [11].

The research results show that the bureaucratic structure is one of the obstacles to the implementation of the tour-guide policy in Bali. This obstacle is due to the fact that Bali Government Tourism Office as the leading sector of tour-guide policies in its bureaucratic structure does not have the authority to carry out the tourguide recruitment process. It only has the authority in issuing KTPP.

Furthermore, the Bali Government Tourism Office cooperates with DPD HPI Bali in the recruitment and service procurement for KTPP applicants. In this condition, problems arise because the involvement of DPD HPI Bali has not 
supported by bureaucratic structures, adequate human resources, or financial resources. It resulted in the KTPP service to seem too slow and bureaucratic. Although there has been coordination, the absence of procedures on clear authority and responsibility can inhibit the coordination structure between organizations [8]. Limited resources do not become a problem if the implementation of this licensing policy has a precise and clear production process.

The bureaucracy structure conception is the extent to which the program mechanism or flow is capable of supporting the policy implementation, so that the programs can be determined from above through existing procedures. One of the aspects is the availability of SOP (Standard Operating Procedures)[10]. SOPs help agencies to use the available time and standardize the employees' actions in their daily activities to be in accordance with agreed procedures. This view illustrates that the unavailability of SOPs in the one-stop service of KTPP in DPD HPI Bali can inhibit the policy implementation. This confused for tour guides regarding KTPP recruitment and control mechanism and procedures.

\section{Political, Economic, and Social Environments}

Policy implementors' attitudes is an external environment unreachable by the implementors, such as the political, social, economic environment. In terms of the economy, Bali tourism is still relied upon to provide opportunities for the Balinese economy, viewed from the increase in the number of tourist visits to Bali every year (Fig. 1). In context, it is undeniable that tour guides play an important role in supporting tourism development in Bali, so their existence will still be recognized and enforced by tourists and existing travel agents [6]. It means that tourism development in Bali still opens up job opportunities for tour guides.

However, viewed from the political and social perspective, the increasing number of visits can inhibit the successful implementation of the tour-guide policy. The inhibition on the political side is that the number of tourist visits is a political decision in the central government. Consequently, tourism is oriented to what is called 'mass tourism'. It means that the decisions determined do not consider the quality, but the quantity of visits, the impact of which is that it is difficult to provide licensed tour guides to certain segments of the tourist market.

In addition, social conditions also do not support the implementation of this tour guide policy. The obstacle is that the local Balinese enthusiasm to pursue jobs as tour guides has decreased, as stated by the Chair of DPD HPI Bali:

"The community's enthusiasm for working as a tour guide decreased because the orientation of some communities is only to get paid with a guide fee, not a basic salary. We were asked to provide tour guides for tourists from certain countries, but there were no applicants in that segment."

Based on the condition, some parties take advantage of opportunities as tour guides without following the prevailing regulations or become illegal tour guides. The thing that needs to be considered to assess the performance of policy implementation is the extent to which the external environment contributes to the success of the public policy. The social, political, and economic environments that are not conducive can fail in the policy implementation [11].

\section{Disposition of Tour Guides}

Implementer's attitude is one of the important factors that influence the success of the policy in achieving its objectives [11]. The tendency of the tour guide's attitude towards license policies is indeed diverse. There are tour guides who comply with the policy rules seen from the issuance of KTPP every year (Fig. 6). The tour guides who tend to be positive have a good understanding of policy objectives, obtain information on the implementation of activities, and financial reasons and comply with coercion.

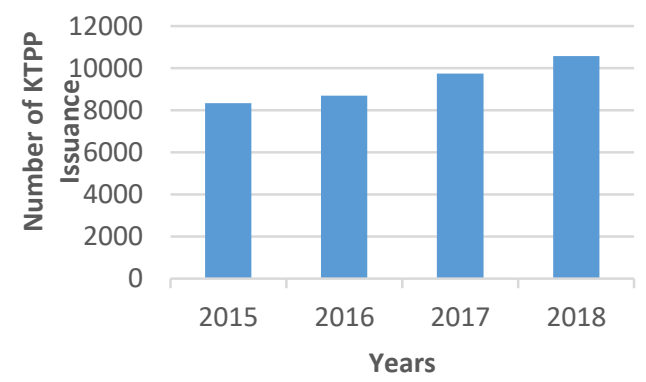

Figure 6. Number of KTPP Issuance for 2015-2018.

(Source: Bali Government Tourism Office)

On the other hand, some guides are actually indifferent. They are objected to the conditions taken, the difficulty in getting the KTPP, or the view that the policy objectives were not in accordance with their work conditions. This condition makes tour guides demanding more on policies that are truly able to add to their experience, not burdening some aspects through licensing. 
Regional Regulation No. 5 of 2016 in Bali requires tour guides to have official permits in the form of KTPP (Tour Guide Identity Card) within one year from the date this regulation applies. However, the presence of illegal tour guides and guides who do not wear traditional Balinese clothing and those who do not extend their KTTP is a tendency for negative attitudes towards the policy (Table 4).

This disposition inhibits the successful implementation of the tour-guide policy in Bali. It seems that the implementation of the tour-guide policy in Bali may be somewhat different from the objectives stated in the regional regulation.

Table 4. Result of Sweeping Violations Tour Guides, 20142018

\begin{tabular}{|c|c|c|c|}
\hline No. & Year & Yustisi* & Non Yustisi* \\
\hline 1. & 2014 & 38 & 43 \\
\hline 2. & 2015 & 0 & 118 \\
\hline 3. & 2016 & 70 & 134 \\
\hline 4. & 2017 & 136 & 64 \\
\hline 5. & 2018 & 91 & 28 \\
\hline \multicolumn{2}{|c|}{ Total } & 335 & 387 \\
\hline
\end{tabular}

Source: Bali Public Order Enforcers, 2018.

Note. Yustisi for tour guides violations without KTPP ownership, non-yustisi for violations on dress ethics and KTPP has a grace period.

Problems in the process of implementing the licensing policy for tour guides were either directly or indirectly related to the problems of inadequate tour-guide quality. Even though it was very clear, it helped to determine tourism quality in Bali. Tourism quality is low. One of the reasons is the low quality of tour guides. This research raises that the problem of tour guides must be resolved comprehensively, not only related to the administration, but also related to all aspects, namely welfare, education, and professional protection.

Tour guide professionalism is built through the license policy needed to do the work. The license policy fulfills the requirements of the competency certificate for tour guides and certificates of Balinese cultural knowledge. Tour guides as professionals are required to constantly improve their abilities, insights, and creativity in guiding tourists. In tourism, tour-guide services are one of the keys that determine the improvement of tourism quality because it is directly related to the tourists guided. Qualified tour guides are always coveted and expected by travel agents and the government because tour guides who have knowledge of Balinese Culture and adequate skills and attitudes according to the code of conduct are believed to be able to provide good service to tourists.

License policy is used by the government to determine whether someone has the right to guide or not. If the government found tour guides who tend to be negative about the policy, it will lead to non-compliance with tour guides, such as not having a license or not extending it. It is feared that the existence of unlicensed tour guides can harm licensed tour guides and can not be accounted for compared to licensed tour guides.

Bali Provincial Government, with the associations (Tour Guides Association (DPD HPI Bali), and Travel Agents Association (ASITA)) and the Bali Public Order Enforcers (Satpol PP Provinsi Bali) always carry out meetings or hearings related to the activities of tour guides. After regular joint meetings about licensed tour guides, the shortcoming referred to, is the lack of supervision of tour-guide activities, therefore many people do tour-guide jobs illegally. The lack of supervision may have negative consequences because the implementation is more dependent on administrative authorities than judicial authorities [8]. Skillful and sustainable supervision is needed. The license policy predicts that only tour guides who have a KTPP can conduct guidance in Bali region, but if there is no supervision and continuous control, it will be difficult to achieve.

\section{CONCLUSION}

The license policy for tour guides in Bali according to Bali Regional Regulation Number 5 of 2016 concerning Tour Guides implemented by Bali Regional Government states that the implementation process has not run according to expectations yet. It is due to the lack of understanding of tour guides for policy objectives and standards, limited financial resources because the source of costs is charged to each tour guides, errors in receiving information due to lack of communication clarity between organizations, lack of clear authority and responsibility procedures in the organization's bureaucracy structure resulting in the delay of KTPP issuance service, and the challenges faced by tour-guides in current social and political conditions that do not support the policy implementation.

These obstacles can substantially lead to the ignorance attitude of tour guides towards the tour-guide policy in Bali. The license policy implementation process that has not been 
optimal resulted in poor compliance and supervision. Preferably, government intervention in the form of a policy is very important, considering the aspects that influence the implementation process.

The research results suggest for further research is related to the research on policy implementation, particularly government regulations on human resource licenses in the tourism sector. This research can be further developed with more cases in other provinces in Indonesia with different economic, social, and political conditions. This condition can be seen from the challenges and gaps in tourism activities. In addition, there is an opportunity to do the research on the tour guide's view of certification, both the content and the impact or the results of its implementation for tour guides.

\section{Acknowledgments}

The author thanks the Bali Government Tourism Office (Dispar Bali), Bali Public Order Enforcers (Satpol PP Bali), Association of Bali Regional Indonesian Guides (DPD HPI Bali), and the tour guides who are members of the DPD HPI Bali who have been involved and provided information in this research.

\section{REFERENCES}

[1] Ap, J. and K. K. F. Wong. 2001. Case study on tour guiding: professionalism, issues and problems. Journal of Tourism Management 22(5), 551-563.

[2] Sharma, S. and N. Chowdhary. 2014. stakeholders' expectations from tour guides. Asia-Pacific Journal of Innovation in Hospital and Tourism 3(1), 41-60.

[3] Lovrentjeva, S. 2015. Education of tourist guides: case of Croatia. Journal Elsevier Procedia Economics and Finance 23, 555562.

[4] Darmawan, I P. E., M. K. Negara, and I P. Sudana. 2017. Pengaruh pelayanan pramuwisata lokal terhadap citra daya tarik wisata Besakih. Jurnal Analisis Pariwisata 17(2), 93-97.

[5] Putra, I GA. G. L. W., I P. Sudana, and N. P. E. Mahadewi. 2016. Analisis kualitas pelayanan pramuwisata terhadap kepuasan wisatawan di PT. Bali Sun Tours. Jurnal Industri Perjalanan Wisata 4(2), 58-63.

[6] Putri, I D. A. H. and N. K. S. Ratmini. 2018. Strategi komunikasi pramuwisata dalam menjaga eksistensi pariwisata Bali. Jurnal Pariwisata Budaya: Jurnal Ilmiah Pariwisata Agama dan Budaya 3(1), 1-19.
[7] Hill, M. and P. Hupe. 2002. Implementing public policy governance in theory and in pratice. Sage Publications. London.

[8] Ap, J. and D. Wang. 2013. factors affecting tourism policy implementation: a conceptual framework and a case study in China. Journal of Tourism Management 36, 221-233.

[9] Krutwaysho, O. and B. Bramwell. 2009. Tourism policy implementation and society. Annals of Tourism Research 37(3), 670-691.

[10] Edward III, G. C. 1980. Implementing public policy. Congressional Quarterly Press. Washington.

[11] van Meter, D. and C. van Horn. 1975. The policy implementation process: a conceptual framework. Administrasion and Society 6(4), 445-88.

[12] Yin, R. K. 2009. Case study research, design and methods $4^{\text {th }}$ Ed. Sage Publications. California.

[13] Black, R. and S. Ham. 2005. Improving the quality of tour guiding: toward a model for tour guide certification. Journal of Ecotourism 4(3), 178-195.

[14] Mazmanian, D. H. and P. A. Sabatier. 1983. Implementation and public policy. Harper Collins. New York. 